\title{
ALTERNATIVA PARA REABILITAÇÃO DE ÁREA ESTÉTICA: RELATO DE CASO
}

Aline Monise SEBASTIANI, Sara Regina TODERO, Rafaela de Moraes SCARIOT, Delson Jõao DA COSTA, Ricardo PASQUINI FILHO

A reabilitação de áreas estéticas é sempre um desafio para os cirurgiões dentistas, aumentando a complexidade no planejamento e execução do tratamento. Paciente do gênero masculino, aos 2 anos de idade, sofreu trauma alvéolo-dentário no incisivo central decíduo do lado direito, afetando o germe do correspondente permanente que sofreu má formação, e erupcionou de forma desfavorável, comprometendo a tábua óssea vestibular, a fixação do dente no alvéolo e a estética do paciente. Ao 15 anos, foi realizada extrusão ortodôntica do incisivo central permanente do lado direito, para se obter um ganho de tecido ósseo e de tecido mole no sentido vertical, nivelando com os tecidos dos dentes ao lado. Aos 18 anos o dente foi extraído, e após um período de 6 meses foi feito enxerto autógeno na região, com osso do ramo mandibular, reestabelecendo um contorno ósseo, e permitindo a colocação do implante em posição favorável para a reabilitação protética. Foi realizado condicionamento gengival com prótese provisória e posteriormente, instalação da prótese definitiva. O paciente encontra-se hoje, com perfeita recuperação da estética. Este caso ressalta a importância de um bom planejamento, acompanhamento em longo prazo e tratamento multidisciplinar.

Palavras-chave: implantes dentários, enxerto ósseo, prótese dentária. 